\title{
Go West, czyli bracia Marx dosiadaja żelaznego konia
}

Bracia Marx w tym sensie wyprzedzali swoje czasy, że burzyli konwencje zarówno samego gatunku filmowego, jak i kina w ogóle, jeszcze zanim ich reguły zdążyły się wykrystalizować.

W roku 1940 (!) powstaje dziesiąty film z udziałem legendarnego tria. Już sam oryginalny tytuł obrazu Go West sugeruje związek z konkretnym modelem narracyjnym westernu, w którym „ze względu na interakcję między bohaterem, społecznością a złoczyńcami” - jak wymienia Jacek Ostaszewski - „grupa bohaterów tworzy społeczność skoncentrowaną wokół wędrówki na Zachód (wyprawy traperów, wędrówka karawany pionierów, budowa kolei itp.) (Żelazny koń, Szlak północno-zachodni [...])”[1]. I to właśnie ten model - dziesiątki lat przed jego wyodrębnieniem w genologii filmu - wybierają sobie Groucho, Chico i Harpo Marx jako temat do wygłupów.

Wyreżyserowany przez Edwarda Buzzela film rozpoczyna się od podanego w formie napisów wprowadzenia:

In 1851, Horace Greelay uttered a phrase that did much to change the history of these United States. He said: "GO WEST, YOUNG MAN, GO WEST". This is the story of three men who made Horace Greelay sorry he said it[2].

Akcja pierwszej sceny rozgrywa się na dworcu kolejowym. Podróżni (wśród których są również bracia) masowo wykupują bilety „na Zachód”, o którym wiadomo tylko tyle, że jest na zachodzie. Nie wiemy, ani dokąd dokładnie, ani też po co ludzie się tam udają. Pierwszym obiektem parodii staje się zatem samo określenie (imperatyw) „na Zachód” - wyśmianiu podlega nie tyle wyidealizowany obraz nowego świata, ile sama wielka misja białych osadników krzewiących cywilizację tam, gdzie jeszcze nie dotarła. Istotnym elementem ikonografii w przywołanej scenie jest czapka traperska („model z roku 1870”) jako symbol wędrówki w wiadomym kierunku. W scenie tej poznajemy również braci Joego i Rusty’ego Panello (Chico i Harpo Marx) oraz oszusta San Quentina Quale’a (Groucho Marx). „To jest Terry Turner. Przyjechał z zachodu" - mówi prezes Kolei Nowojorskiej, podkreślając w ten sposób, że mężczyzna jest kimś ważnym. Turner (John Carroll) namawia władze kolei, by jej kolejny odcinek biegł przez tzw. Trupi

[1] J. Ostaszewski, Konteksty westernu, w: Kino gatunków, pod red. A. Helman, Wydawnictwo Rabid, Warszawa-Kraków 1991, s. 74-75.
[2] W roku 1851 Horace Greelay wyrzekł słowa, które zmieniły historię Stanów Zjednoczonych: „RUSZAJ NA ZACHÓD, MŁODZIEŃCZE”. Oto historia trzech ludzi, przez których Horace Greelay pożałował tych słów. 
Wąwóz. Bohater nie ukrywa, że dzięki takiemu rozwiązaniu będzie mógł ożenić się z kobietą, którą kocha. Może pozwolić sobie na taką szczerość, ponieważ przyjechał z Zachodu, a to - jak się okazuje - wystarcza, żeby w pełni mu zaufać, nawet jeśli motywacje są natury osobistej.

Trupi Wąwóz należy do dziadka wybranki Turnera, Dana Wilsona. Jeśli kolej kupi jałową, bo pozbawioną złota ziemię, którą za bezcen sprzedał Wilsonowi dziadek Turnera, konflikt pomiędzy dwoma zwaśnionymi rodami zostanie zażegnany, a bohater będzie mógł się połączyć ze swoją wybranką. Trzeba tylko zdobyć akt własności ziemi.

To właśnie swoista walka o dokument stanowi oś fabularną konfliktu, a historia opowiedziana jest w taki sposób, by (po drodze) wyśmiać niemal wszystkie elementy stanowiące kwintesencję filmowego westernu.

Konteksty i gra z konwencjami
Sam temat filmu, wysuwając na plan pierwszy motyw budowy amerykańskiej kolei transkontynentalnej, odsyła nas bezpośrednio do, przywołanego już zresztą, Żelaznego konia (1924), jednego z niekwestionowanych arcydzieł kina niemego, a po części również do Generała (1926) Bustera Keatona. I choć w Go West sam proces budowy linii jest niemal niewidoczny, warto wskazać film Johna Forda jako ważny kontekst.

Żelazny koń był pięćdziesiątym filmem Johna Forda (większość z nich zrealizował pod pseudonimem Jack Ford) i od razu został uznany za wielkie osiągnięcie artystyczne. Logicznie prowadzona akcja, wzruszający wątek melodramatyczny, wspaniałe pejzaże Monument Valley i gór Sierra Nevada, efektownie fotografowane przez George’a Schneidermana, wzorującego się na XIX-wiecznym amerykańskim malarstwie pejzażowym spod znaku Alberta Bierstadta i Fredericka Churcha, tłumy statystów, w tym Indian, dziesięć tysięcy sztuk bydła i tysiąc trzysta bizonów - wszystko to robiło potężne wrażenie[3].

Większość elementów, które w kontekście filmu Forda wymienia Łukasz Plesnar, odnajdziemy również w Go West, z tym że w nieco skromniejszej, za to przepełnionej najwyższej klasy humorem formie. To właśnie rozsławiona przez Johna Forda, a leżąca na dawnych terenach Indian Navaho, Monument Valley "gra” w Go West bezcenny jak się potem okazuje - Trupi Wąwóz[4]. Bracia Panello w tych właśnie „okolicznościach przyrody” kupują od Dana Wilsona akt własności ziemi. A fakt, że płacą zań jedyne 10 dolarów, wystarcza, aby zrozumieć desperację jej, byłego już teraz, właściciela. Wilsonowi - jak sam podkreśla - zależy tylko i wyłącznie na przyszłości wnuczki, którą chciałby wesprzeć finansowo. Mężczyzna marzy już teraz jedynie o niewielkim udziale w kopalni złota, a otrzymane przed chwilą 10 dolarów zamierza przeznaczyć na ten cel.
[3] Ł.A. Plesnar, Twarze westernu, Wydawnictwo Rabid, Kraków 2009, s. 117.
[4] Autorem scenografii był Cedric Gibbons. 
Niczego nieświadomy Terry udaje się do swojej ukochanej. Jest pewien, że po finalizacji kupna ziemi przez kolej zyska wreszcie przychylność dziadka swojej wybranki. Eve Wilson (Diana Lewis) reaguje na wiadomość w sposób tak entuzjastyczny, jak wyrafinowany. Dialogi typowe dla sophisticated comedy w scenerii Dzikiego Zachodu zestawione zostały w tej scenie z niezwykle ckliwą muzyką. Dokładając kontekst dwóch zwaśnionych rodów, możemy interpretować to, co widzimy na ekranie, bardziej w kategoriach pastiszu niż parodii. Galopujący, a potem widowiskowo zsiadający z konia, Romeo nie jest w tej scenie postacią komiczną. To samo tyczy się wychodzącej o blasku księżyca przed hacjendę Julii. Jedno jest pewne - wątek melodramatyczny, tak jak w Żelaznym koniu, odgrywa w filmie niepoślednią rolę.

Wspomniana walka o akt własności Trupiego Wąwozu to już istna wariacja na temat filmowego westernu.

„Rusty, nie lubię Zachodu, ludzie bez przerwy się tu mordują” komentuje strzelaninę przy saloonie Joe. Rewolwerowcem, który przed chwilą z uśmiechem na ustach zakończył swoje porachunki, jest niejaki „Red” Baxter. Bandzior otrzymuje telegram o treści: „Drogi Redzie, zdobądź akt własności, bo nie zmusimy kolei do kupna naszej ziemi po naszej cenie. Beecher". Ich ziemia to teren położony na północ od równie ciekawie brzmiącego - Cripple Creek. Zdobycie aktu własności umożliwi zatem parze czarnych charakterów zgarnięcie fortuny bez względu na to, jaką trasę wybierze kolej.

Od tej chwili akt własności Trupiego Wąwozu krąży stale pomiędzy braćmi Panello (do których wkrótce dołączy również San Quentin Quale) a duetem Baxter \& Beecher.

Oszust Quale po wynegocjowaniu aktu własności za sumę 6000 dolarów pewien jest, że otrzyma zań prawie dwa razy tyle. Staje się jednak ofiarą innego oszusta - Reda Baxtera, który zostawia go z niczym. W scenie tej - brawurowo zagranej przez Groucho - sparodiowaniu ulega westernowy motyw pojedynku, a punkt wyjścia stanowią przechwałki rewolwerowców. W klasycznym westernie każdy za wszelką cenę chce dowieść, iż jest lepszym strzelcem niż jego przeciwnik, wyznaczając sobie coraz to trudniejsze cele. W Go West motyw ten ulega oczywiście wyśmianiu. "Widzisz muchę na czubku nosa?” - zapytuje Quale Reda, wskazując na siedzącego przy barze pijaka. „To znaczy, że masz dobry wzrok" - puentuje. Innym razem bohater - nie mogąc uporać się z kaburą i parą koltów - oznajmia: „Nie rozumiem, jak oni panują nad tym wszystkim, jadąc na koniu”. Zamiana rewolwerów na szczotki przez Rusty’ego, mknący na dwóch kołach dyliżans i kapitalna scena schadzki z dwulicowymi prostytutkami to jednak tylko przedsmak tego, co wydarzy się po przybyciu braci do wioski Indian.

Model westernu z motywem wędrówki na Zachód od początku związany był z tematem Indian. W Żelaznym koniu czerwonoskórzy przedstawieni są jako ci, którzy stanowią jedno z największych zagrożeń

Rdzenni mieszkańcy Ameryki z punktu widzenia krzewienia cywilizacji - utrudniają oni bowiem 
proces budowy linii kolejowej, siejąc spustoszenie i śmierć. W Go West pojawienie się Indian nie ma jednak bezpośredniego związku z tematem technologicznego scalenia Wschodu $\mathrm{z}$ Zachodem, a sam wizerunek rdzennych mieszkańców Ameryki odbiega znacznie od obrazu, do jakiego kino przyzwyczaiło ówczesnego widza westernów. Jak pisze Jacek Ostaszewski:

O Indianach w westernie pisano wiele [...], ale może warto zwrócić uwagę na jeden aspekt w ich filmowym obrazowaniu. Otóż najczęściej w tradycyjnym westernie wigwamy wioski indiańskiej ustawione były frontem do jej centralnego punktu. Stanowił go... słup tortur, miejsce kaźni Białego. Indiańska wioska funkcjonowała jako alegoria Zła, Piekła (Niezwyciężony Bill, 1937, C. de Mille’a z Gary Cooperem w roli głównej). W latach pięćdziesiątych western na szeroką skalę podjął akcję rehabilitacji Indian. W filmie Sama Fullera Run of the arrow (1957) obóz indiański leży nad przejrzystą rzeką. Życie płynie tam spokojnie, jak gdyby czas się zatrzymał. Wioska staje się wyobrażeniem dziecięcego wieku ludzkości, symbolem odnalezionego Edenu [...][5].

Gwoli ścisłości dodajmy, że na film Fullera, jako prekursora prób zmiany wizerunku Indian w kinie, powołuje się również Łukasz Plesnar[6]. Wróćmy jednak do Go West. Obraz indiańskiej wioski - abstrahując na razie od faktu, że mamy do czynienia z komedią - zbliżony jest tu raczej do tego zaprezentowanego w Run of the arrow (1957!). Po przybyciu na miejsce Terry wypowiada zdanie: „Indianie są przyjaźni, jeśli ich dobrze traktować”. I tacy też się okazują. Wioska Indian staje się dla naszych bohaterów swego rodzaju azylem, w kontekście dalszej podróży (muszą przecież jeszcze dotrzeć do najbliższej stacji, a stamtąd pociągiem do Nowego Jorku, gdzie sfinalizują sprawę kupna przez kolej Trupiego Wąwozu). Życie faktycznie płynie tu „jak gdyby czas się zatrzymał”. Bracia Marx również w odniesieniu do tego problemu badawczego wyprzedzili zatem swoje czasy. Co więcej, samo zagadnienie konfrontacji i próba nawiązania kontaktu z czerwonoskórymi posłużyły tu jako temat do stworzenia - jednej z najlepszych w całym filmie - serii gagów.

Ów nowy rozdział otwiera scena spotkania $\mathrm{z}$ wodzem plemienia. „Mówisz po indiańsku?” - zwraca się Quale do Joego. „Urodziłem się w Indianapolis” - słyszy w odpowiedzi. Szybko okazuje się jednak, że język mieszkańców Indianapolis różni się od języka tubylców. „Nawet nie mówisz po indiańsku. Wyrecytuj Hiawathe Henry'ego Wadswortha Longfellowa” - rzuca wyzwanie przywódcy czerwonoskórych Quale. Język „białych” zna z kolei tylko Indianka, która nie ma najmniejszej ochoty na nawiązanie bliższego kontaktu z gośćmi. Gardzi naszyjnikiem carycy, bo woli cadillaca. „Widać, że nie pochodzi z rezerwatu” - puentuje całe zajście Quale. Przełom następuje dopiero wówczas, gdy do akcji wkracza Rusty. Barierę językową udaje się zatem pokonać komuś, kto paradoksalnie... nie mówi. 
A dzieje się to za sprawą uniwersalnego języka... muzyki. Wódz plemienia jest zafascynowany klaksonem Rusty’ego, a ten - podchwytując temat - rogami szamana, na których $\mathrm{w}$ duecie $\mathrm{z}$ Joem wygrywa prostą melodię w rytmie walca. Po chwili do występu dołącza się również Quale, intonując rzewną pieśń.

Muzyczne wyczyny braci Marx to w filmach z ich udziałem niemal stały punkt programu. Do historii kina przeszły zarówno brawurowe popisy wirtuoza fortepianu - Chico, jak i nastrojowe kompozycje wygrywane przez jego młodszego brata na harfie (stąd zresztą wziął się jego przydomek). W takich filmach, jak Noc w operze i Dzień na wyścigach, sceny te nie odgrywały jednak jeszcze tak doniosłej roli w odniesieniu do dramaturgii filmu. Stanowiły raczej coś w rodzaju ornamentu, współtworząc nastrój miejsca. Co więcej, w obu przywołanych tytułach występ Harpo następował bezpośrednio po występie jego starszego brata, a sam repertuar nie korespondował w sposób zbyt wyrafinowany z tematyką danego obrazu - dla przykładu, w filmie Noc $w$ operze Chico interpretuje jazzowy standard All I Do is Dream of You.

Rozsławiony przez Orkiestrę Glenna Millera i The Andrews Sisters, a wykonywany przez najstarszego z braci, przebój The Woodpecker Song[7] nie wywodzi się, co prawda, w prostej linii z tradycji muzyki country. Kluczowa jest natomiast interpretacja utworu, który w wykonaniu artysty bezsprzecznie oddaje ducha Dzikiego Zachodu. Scena, o której mowa, rozgrywa się w saloonie bezpośrednio po odzyskaniu przez braci aktu własności Trupiego Wąwozu. Filmowy Joe jest do tego stopnia uradowany takim obrotem spraw, że pod wpływem impulsu siada przy fortepianie i po prostu zaczyna grać.

Na występ jego młodszego brata widz musi natomiast poczekać (w znaczeniu pozytywnym) do momentu, kiedy protagoniści trafią do, przywołanej już wcześniej, indiańskiej wioski. Przywódca czerwonoskórych otrzymuje od Rusty'ego krótki kurs gry na flecie, po czym obaj „muzycy” rozpoczynają wspólne granie. Harfa indiańska nieco różni się wyglądem od tej z opery, niemniej jej skromne możliwości wystarczają, by Rusty wspólnie $\mathrm{z}$ wodzem odegrał szlagier From the Land of Sky-Blue Water[8]. Scena ta pełni ponadto bardzo ważną funkcję właśnie z punktu widzenia dramaturgii filmu - jest to czas na złapanie oddechu przed mającą dopiero nastąpić częścią finałową, która rozegra się na pokładzie żelaznego konia.

Omawiając funkcje muzyki w Go West, nie można nie wspomnieć o dwóch kompozycjach Bronisława Kapera. Piosenki polskiego kompozytora rozbrzmiewają w musicalowych scenach filmu. You Can't Argue With Love wykonuje na scenie dziewczyna Reda Baxtera, Lulubelle (June McCloy), misternie uwodząc przy tym Quale'a. Cho- 
dzi - jak zwykle zresztą - o zdobycie aktu własności Trupiego Wąwozu. Eve Wilson, czekając na swojego ukochanego, nuci natomiast As If I Didn't Know.

Jeszcze jeden utwór z musicalowego programu Go West zasługuje na uwagę - mowa o Ridin' The Range[9]. Piosenkę, która jest swego rodzaju hołdem dla niezmordowanych koni, wykonuje w drodze do wioski Indian trio: Terry Turner, San Quentin Quale \& Joe Panello. Akompaniuje im Rusty, przygrywając na harmonijce ustnej. Gwoli ścisłości dodajmy, że autorem tekstów wszystkich piosenek rozbrzmiewających w scenach musicalowych był Gus Kahn. Uważny widz zauważył ponadto, że Ridin' The Range słyszymy (w wersji instrumentalnej) również w czołówce filmu.

Twórcy obrazu, w trosce o jak najwierniejsze oddanie atmosfery Dzikiego Zachodu, zamieścili w ścieżce dźwiękowej także kilka standardów muzyki country - m.in. słynny kawałek Oh Suzanna, który w różnych wersjach (w jednej ze scen piosenka jest nucona przez Groucho) rozbrzmiewa w Go West, przypominając widzowi o czasie i miejscu akcji filmu.

Wielki finał

Western, musical, ale przede wszystkim komedia. Powiedzieć jednak, że Go West jest parodią tudzież wariacją na temat westernu, to nic nie powiedzieć. Bracia Marx poza tym, że - jak słusznie zauważa Marek Hendrykowski[10] - byli królami filmowej farsy, wykorzystywali również elementy innych wyodrębnionych przez badacza odmian komedii. W odniesieniu do konstrukcji, niepoślednią rolę odgrywa w Go West tradycja filmowego slapsticku, nierozerwalnie związana z postacią słynnego aktora, reżysera i producenta filmowego Macka Sennetta. Jak pisze Marek Hendrykowski:

To Sennett (notabene uczeń Davida Warka Griffitha uważający montaż za klucz do sztuki filmowej) wykreował podstawowe reguły slapsticku jako ekranowego widowiska i on również wypracował zasadę jego prostej dwuczęściowej konstrukcji dramaturgicznej z perypetiami w części pierwszej i przybierającą z czasem rozmiary zagarniającego wszystkich i wszystko huraganu pogoni w części finałowej. Konstrukcja ta, sprawdzona w tysiącach filmów, okazała się swego rodzaju kamieniem węgielnym budowy slapsticku, na którym powstała niezliczona liczba wspaniałych komedii[11].

Jednym z tysiąca tych obrazów jest również Go West. Wszystkie przywołane do tej pory sceny filmu to perypetie, pogoń rozpoczyna się natomiast w chwili, kiedy protagoniści wchodzą na pokład żelaznego konia. Pociąg musi dotrzeć do Nowego Jorku przed bandą Reda Baxtera, w przeciwnym razie akt własności Trupiego Wąwozu straci wartość. To właśnie determinacja, z jaką bracia podejmą się tego karkołomnego - jak się okaże - zadania, będzie źródłem owej niszczycielskiej siły,

[9] Muz. Roger Edens.

[10] Zob. M. Hendrykowski, Komedia filmowa wczoraj i dziś, w: Kino gatunków - wczoraj i dziś, pod. red. K. Loski, Wydawnictwo Rabid, Kraków 1998,

s. 71 .

[11] Ibidem, s. 73 . 
pochłaniającej wszystko, co tylko stanie im na drodze. Pojawienie się pociągu w ostatnich scenach filmu ma oczywiście również wymiar symboliczny - krzewienie cywilizacji (przypomnienie). Motyw amerykańskiej kolei transkontynentalnej i scalenie Wschodu z Zachodem to przecież główny temat opowieści, sam pociąg pojawia się jednak dopiero w ostatnich dwudziestu minutach filmu. W tych scenach nie istnieją już jednak żadne reguły, a jazda odbywa się dosłownie bez trzymanki.

Poza charakterystyczną dla sophisticated comedy słowną szermierką [12] w Go West mamy również do czynienia z szermierką sensu stricto. I nie byłoby może w tym nic nadzwyczajnego, gdyby nie fakt, że za białą broń posłużyły naszym bohaterom... oliwiarki. W filmie Noc $w$ operze Harpo podobnie sfunkcjonalizował batutę dyrygencką, prowadząc pojedynek z całą orkiestrą, w Go West jego przeciwnikami są palacz i maszynista. Obaj ponoszą klęskę, po czym zostają solidnie związani przez braci, którzy przejmują stery. Z uwagi na fakt, że „podręcznik dla maszynisty jest bezużyteczny, jeśli nie ma maszynisty”, San Quentin Quale postanawia, że poradzi sobie bez niego, za to z pomocą Joego. Wszystko idzie zgodnie z planem. Rozpędzony pociąg mknie z zawrotną prędkością. Pytanie brzmi jednak, jak go teraz zatrzymać po drodze trzeba przecież „zgarnąć” Terry’ego i Eve.

- Jak to się zatrzymuje? - pyta Quale spętanego maszynistę.

- Hamulcem, hamulcem - odpowiada przerażony mężczyzna.

- To najlepszy gag w całym filmie - mówi, zwracając się do widzów, Quale.

Niestety, hamulec zostaje złamany przez Rusty’ego, który oczywiście chciał dobrze, a wyszło na opak. Podobnie dzieje się, kiedy nasz bohater, chcąc zalać palenisko, wlewa do komina substancję zawierającą łatwopalne wodorowęglany - pociąg mknie jak szalony. Na domiar złego, na pokładzie żelaznego konia przebywa również duet czarnych charakterów. Protagoniści muszą zatem stoczyć kolejny pojedynek tym razem na szczapy drewna, które - podobnie jak oliwiarki - znakomicie sprawdzają się w roli białej broni. Baxter i Beecher po przegranej walce zostają umieszczeni w wagonowej toalecie. „W razie problemów dzwońcie" - puentuje całe zajście Quale. Choć - jak sam stwierdza w jednej ze scen - „Jest rok 1870, Graham Bell nie wynalazł jeszcze telefonu”. Parę antagonistów uwalnia dopiero Lulubelle. Kiedy pociąg udaje się wreszcie zatrzymać, do braci dołączają Eve i Terry. Beecher z Baxterem przesiadają się natomiast na konny powóz, rozpoczynając wyścig z maszyną, który w ich mniemaniu jest wygrany, ponieważ ich przeciwnikom kończy się opał.

Czego się jednak nie robi dla pary zakochanych? Jeśli wagony wykonane są $\mathrm{z}$ drewna, to czemu nie przetworzyć zbędnej materii na niezbędną energię? Można nawet dorzucić do pieca trochę masła, „tak brzmi jak diesel”. Rusty ostrzy siekierę, wykorzystując do tego celu obracające się koło pociągu i już po chwili zebrana zostaje całkiem pokaźna porcja opału.

[12] Zob. ibidem, s. 76 . 
Poza odkrywaniem nieznanych funkcji znanych przedmiotów (oliwiarki i szczapy w roli białej broni, koło pociągu jako szlifierka) ciekawym pomysłem w tej części filmu jest również totalne zakwestionowanie praw fizyki. Scena, w której Rusty próbuje w trakcie jazdy spiąć ze sobą dwa rozłączone wagony, dosłownie zwala z nóg. Protagonista, niczym superbohater $\mathrm{z}$ filmów science fiction, wydłuża się, jakby był z gumy, a po wykonaniu zadania wraca do swojego pierwotnego kształtu. W wyniku zdemontowania torów przez parę antagonistów pociąg wyskakuje z szyn, jeżdżąc w kółko po miejscowej posiadłości niczym karuzela i zmiatając wszystko, co tylko staje mu na drodze (z drewnianą chatą włącznie). Wóz z Beecherem i Baxterem wjeżdża natomiast analogicznie na tory, na których niespodziewanie znów pojawia się ogołocony z wszelkich drewnianych elementów pociąg. Tym samym negatywne postacie zostają ostatecznie pokonane, a bohaterowie cieszą się ze zwycięstwa.

Ostatnia scena filmu to kolejne nawiązanie do niezapomnianego Żelaznego konia. Bohaterowie świętują moment spotkania się dwóch linii kolejowych - wschodniej i zachodniej. Od tej pory, jak możemy się domyślać, obie stanowić będą jedną - transkontynentalną, biegnącą od wybrzeży Atlantyku do Pacyfiku. W kadrze pojawiają się natomiast dwa parowozy skierowane frontem do siebie (tak jak w filmie Johna Forda). Pada wymowna kwestia: „A teraz, panie i panowie, prezes Kolei Nowojorskiej i Zachodniej przetnie wstęgę i wbije kołek, otwierając nową kolej. Orkiestra, grać!”. W uznaniu zasług zaszczyt wbicia kołka otrzymują jednak bracia, a sam prezes pod wpływem zamachu, jaki bierze Rusty, zostaje dosłownie wbity w ziemię. Podobnie jak w Żelaznym koniu (i Generale Bustera Keatona) temat kolei oraz Zachodu koresponduje w Go West z historią miłosną, a w finale wszystkie konflikty zostają harmonijnie rozwiązane. „Kiedy wbiją ostatni gwóźdź, będziemy należeć do obu stron i do siebie samych" - mówi do swej ukochanej główny bohater filmu Forda.

Trzej bracia Marx wykorzystują formułę znaną z wcześniejszych obrazów z ich udziałem - wchodzą w skonwencjonalizowaną rzeczywistość, rozbijając jednocześnie jej umowny porządek. Jak pisze Dorota Skotarczak:

Bracia Marx są w dziejach sztuki filmowej zjawiskiem niezwykłym, w zasadzie nie mającym żadnego odpowiednika. W skrzących się od błyskotliwych dialogów filmach dokonują całkowitej destrukcji ukazywanej na ekranie rzeczywistości. Nie liczą się przy tym z jakimikolwiek ograniczeniami, działają kierując się sobie tylko znanymi przesłankami, są szaleni i zwariowani, w sumie robią wszystko, na co mają ochotę. Na ekranie prezentują totalny anarchizm i swobodę działania[13].

[13] D. Skotarczak, Historia amerykańskiego musicalu

filmowego, SF Montevideo, Wrocław 2000, s. 29. 
Go West jest jednak w odniesieniu do tego problemu filmem wyjątkowym, gdyż owa „swoboda działania” przejawia się w nim na kilku płaszczyznach. Znamienne jest przede wszystkim zagadnienie czasu i miejsca akcji filmu. Groucho, Chico i Harpo docierają na Dziki Zachód w drugiej połowie XIX wieku, pozostając jednak sobą w stu procentach! Stwarza to podwójne, a nawet potrójne możliwości tworzenia najrozmaitszych gagów. Po pierwsze - wyśmiane zostaje konkretne społeczeństwo, tudzież grupy społeczne (nic nowego), po drugie - zostaje ono wyśmiane przez „przybyszów z przyszłości” (pryzmat) i wreszcie po trzecie, co wiąże się z drugim - sparodiowaniu ulega już nie tylko sama rzeczywistość ze swymi konwenansami, ale również konkretny gatunek filmowy (konwencja), a na samym końcu także medium filmu. 


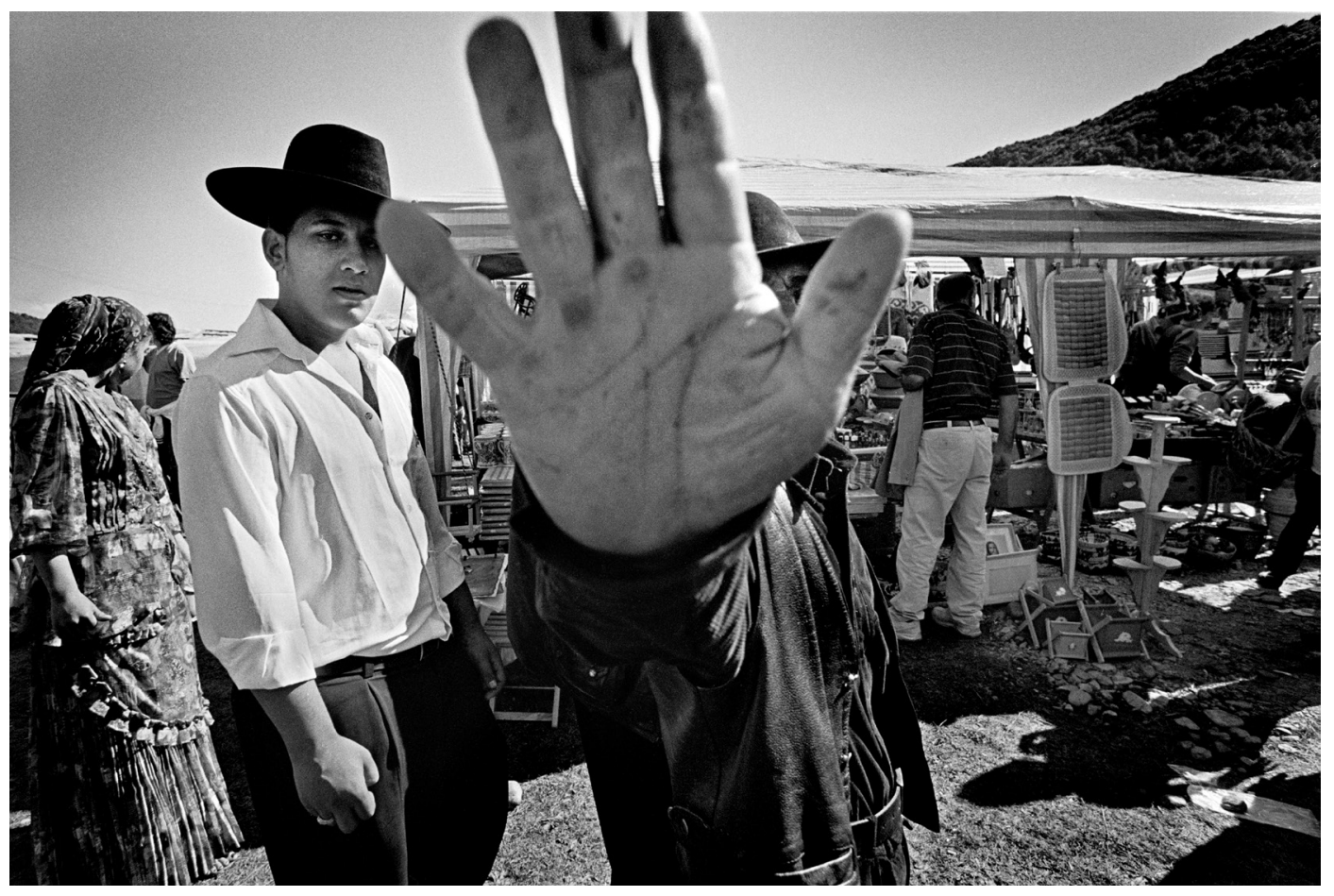

Fot. Maciej Łabudzki 